\title{
DERIVING MACROECONOMIC BENEFITS FROM PUBLIC-PRIVATE PARTNERSHIPS IN DEVELOPING ASIA
}

\author{
Minsoo Lee, Xuehui Han, Raymond Gaspar, and Emmanuel Alano
}

NO. 551

August 2018
ADB ECONOMICS WORKING PAPER SERIES 
ADB Economics Working Paper Series

\section{Deriving Macroeconomic Benefits from Public-Private Partnerships in Developing Asia}

Minsoo Lee, Xuehui Han, Raymond Gaspar, and Emmanuel Alano

No. 551 | August 2018
Minsoo Lee (mlee@adb.org) is a Senior Economist, Xuehui Han (xhan@adb.org) is an Economist, Raymond Gaspar (rgaspar.consulant@adb.org) and Emmanuel Alano (ealano.consultant@adb.org) are consultants in the Asian Development Bank.

This paper has been prepared as background material for the Asian Development Outlook 2017 Update theme chapter on Sustaining Development through PublicPrivate Partnership. 
(C) 2018 Asian Development Bank

6 ADB Avenue, Mandaluyong City, 1550 Metro Manila, Philippines

Tel +632632 4444; Fax +6326362444

www.adb.org

Some rights reserved. Published in 2018.

ISSN 2313-6537 (print), 2313-6545 (electronic)

Publication Stock No. WPS189465-2

DOI: http://dx.doi.org/10.22617/WPS189465-2

The views expressed in this publication are those of the authors and do not necessarily reflect the views and policies of the Asian Development Bank (ADB) or its Board of Governors or the governments they represent.

ADB does not guarantee the accuracy of the data included in this publication and accepts no responsibility for any consequence of their use. The mention of specific companies or products of manufacturers does not imply that they are endorsed or recommended by ADB in preference to others of a similar nature that are not mentioned.

By making any designation of or reference to a particular territory or geographic area, or by using the term "country" in this document, $A D B$ does not intend to make any judgments as to the legal or other status of any territory or area.

This work is available under the Creative Commons Attribution 3.0 IGO license (CC BY 3.0 IGO)

https://creativecommons.org/licenses/by/3.0/igo/. By using the content of this publication, you agree to be bound by the terms of this license. For attribution, translations, adaptations, and permissions, please read the provisions and terms of use at https://www.adb.org/terms-use\#openaccess.

This CC license does not apply to non-ADB copyright materials in this publication. If the material is attributed to another source, please contact the copyright owner or publisher of that source for permission to reproduce it. $\mathrm{ADB}$ cannot be held liable for any claims that arise as a result of your use of the material.

Please contact pubsmarketing@adb.org if you have questions or comments with respect to content, or if you wish to obtain copyright permission for your intended use that does not fall within these terms, or for permission to use the ADB logo.

Notes:

In this publication, "\$” refers to United States dollars.

ADB recognizes "Korea" as the Republic of Korea.

Corrigenda to ADB publications may be found at http://www.adb.org/publications/corrigenda. 


\section{CONTENTS}

TABLES AND FIGURES

ABSTRACT $v$ V

$\begin{array}{ll}\text { I. INTRODUCTION } & 1\end{array}$

II. THE EMERGENCE OF PUBLIC-PRIVATE PARTNERSHIPS IN ASIA 2

III. INFRASTRUCTURE, MACROECONOMY, AND POVERTY 4

A. Public-Private Partnerships and the Macroeconomy 5

B. The Channels of Public-Private Partnerships Impacts 5

IV. $\quad$ DATA AND EMPIRICAL APPROACH 7

A. $\quad$ Growth Determinants 7

B. Public-Private Partnership Investment Data: Sources, Issues, and Adjustments 8

C. Channels for Macroeconomic Impact and Poverty Reduction 8

V. $\quad$ EMPIRICAL FINDINGS 9

A. PPP Investment Booms 9

B. Public-Private Partnership Readiness 10

C. Public-Private Partnership Investments and Real GDP Growth 11

D. Infrastructure Access and Quality 13

VI. CONCLUSION AND POLICY RECOMMENDATIONS

$\begin{array}{ll}\text { APPENDIX } & 17\end{array}$

$\begin{array}{ll}\text { REFERENCES } & 21\end{array}$ 


\section{TABLES AND FIGURES}

\section{TABLES}

$1 \quad$ Public-Private Partnership and Economic Growth in Developing Asia 12

2 Public-Private Partnership, and Infrastructure Access and Quality in Developing Asia 14

3 Effect of Increasing Public-Private Partnership Investments as Percentage of GDP 15 in Developing Asia

A1 Variables, Definitions and Data Sources for the Analysis 17

A2 Public-Private Partnership Investment Ratio to Total Infrastructure Investment 18 in 18 Developing Asian Economies, 2011

A3 Public-Private Partnership and Sectoral Employment in Developing Asia 19

A4 Education PPP and Enrollment Rates 20

\section{FIGURES}

1 Infrastructure Public-Private Partnership Projects in Developing Regions, 1985-2015 2

2 Infrastructure Public-Private Partnership Projects in Developing Asia, 1985-2015 3

3 Infrastructure Public-Private Partnership Projects by Sector in Developing Asia, 1985-2015 3

$4 \quad$ Public-Private Partnership-Economic Growth-Poverty Nexus 6

5 Real Per Capita Gross Domestic Product Growth Before and After a PPP Investment Boom 10

6 Average Real per Capita Gross Domestic Product Growth and Capabilities to Manage 10 Public-Private Partnerships

$7 \quad$ Public-Private Partnership Readiness Score in Asia and the Pacific, 2014 


\begin{abstract}
The provision of infrastructure and related services in developing Asia via public-private partnership (PPP) increased rapidly during the late 1990s. Theoretical arguments support the potential economic benefits of PPPs, but empirical evidence is thin. This paper develops a framework identifying channels through which economic gains can be derived from PPP arrangement. The framework helps derive an empirically tractable specification that examines how PPPs affect the aggregate economy. Empirical results suggest that increasing the ratio of PPP investment to GDP improves access to and quality of infrastructure services, and economic growth will potentially be higher. But this optimism is conditional, especially on the region's efforts to further upgrade its technical and institutional capacity to handle complex PPP contracts.
\end{abstract}

Keywords: developing Asia, economic growth, infrastructure, poverty reduction, public-private partnership

JEL codes: H54, O11, O18, O47 


\section{INTRODUCTION}

An abundance of theoretical and empirical evidence recognizes the vital role of infrastructure to stimulate and sustain economic growth. Stable power supplies, paved roads, and advanced information and communication technology (ICT) infrastructure improves productivity and competitiveness. Developing Asia's robust growth has in no small measure benefited from great strides made in building and upgrading infrastructure. But the region is nowhere close to straddling its huge infrastructure gap, which public resources alone cannot meet. The Asian Development Bank (ADB) (2017) estimates the infrastructure investment gap, measured as the difference between investment needs and current investment, equivalent to 2.4\% of projected annual gross domestic product (GDP) from 2016 to 2020. With vast financial resources available, the private sector could help, particularly through public-private partnerships (PPPs) by making infrastructure projects bankable endeavors. There is an estimated $\$ 100$ trillion in global assets managed by pension funds, sovereign wealth funds, insurance companies, and other institutional investors (Arezki et al. 2016).

The very effectiveness of PPPs for infrastructure development is based on structural and functional features that traditional procurement lacks. These include a life-cycle perspective on infrastructure, innovative financing, a focus on service delivery, and risk sharing by public and private sector partners. The big question is whether and to what extent these features create additional economic growth. This paper looks at the policy implications of this for developing economies in Asia that badly need more infrastructure, but do have limited resources and capacity to handle the complex processes of PPP projects. Theoretical arguments support the potential economic benefits of PPPs, but the empirical evidence is thin. To our knowledge, this study is one of the few attempts to empirically examine how PPPs affect the aggregate economy, although micro-level analysis of specific projects, including PPPs, are on the rise.

Guided by the literature on PPPs, this paper identifies the four main channels through which these partnerships can potentially boost economic growth. The first and obvious channel is improving access to infrastructure, particularly to a desired level of quality. Efforts to enhance quality are likely to be more pronounced in PPPs because of the transfer of operating risks in PPP contracts.

The second channel highlights the benefits from improving technical and institutional capacity, transparency, and good governance from partnerships with the private sector. The third channel involves how PPPs facilitate better allocation of public resources. If PPPs deliver better infrastructure services, the public sector can deploy more resources into essential services in education, health, and social security. The fourth channel is the potential of PPPs to attract private savings in long-term investments, such as pension, insurance, and sovereign wealth funds. Matching long-term savings with bankable PPP projects will optimize resource allocation and contribute to economic growth (Arezki et al. 2016).

Empirical evidence indicates a significant positive macroeconomic contribution of PPPs. Following on from this, PPPs-and especially social and pro-poor infrastructure-has an essential role to play in efforts to reduce poverty by improving access to infrastructure and markets.

The remainder of the paper is structured as follows. Section II discusses the emergence of PPPs in developing Asia. Section III reviews existing literature and draws out a conceptual framework that examines the relationship between macroeconomy, poverty, and infrastructure, which includes those delivered via PPPs. Section IV describes the data, stylized facts, and the empirical approach. Section V presents the empirical findings and section VI concludes and recommends policy actions. 


\section{THE EMERGENCE OF PUBLIC-PRIVATE PARTNERSHIPS IN ASIA}

The participation of the private sector in public infrastructure in Asia has its origins in the wave of privatizations of the 1980s and 1990s. Back then, rising evidence of inefficient spending, poorly managed state-owned enterprises, and widespread fiscal and debt crises called for a new model of economic development led by the private sector and market liberalization. Henckel and McKibbin (2010) note that the private sector's involvement in infrastructure, either exclusively or through PPPs, is motivated by inefficiencies observed in public projects, such as cost blowouts, planning and construction delays, safety problems, and a lack of innovation and technological advancement.

Figure 1 shows the gradual rise of PPP transactions in developing regions since the mid-1980s. The World Bank's Private Participation in Infrastructure database records 6,124 infrastructure PPP projects, totaling \$1.7 trillion from 1985 to 2015 among 139 low- and middle-income countries. Infrastructure PPP projects in developing Asia started to increase rapidly from the late 1990s. Over 1985-2015, the region closed more than 3,000 infrastructure PPP projects, totaling $\$ 661$ billion in committed investment.

Within developing Asia, PPP implementation varies (Figure 2). The surge in financial closure of PPPs in 2011 and 2012 came mostly in East and South Asia. PPPs in Central Asia and the Pacific were low over the period, but those in Southeast Asia showed a rising trend, especially for Indonesia, Malaysia, Thailand, the Philippines and Viet Nam. By country, India and the People's Republic of China had the highest number of infrastructure PPPs, totaling a combined 2,145 projects in the period. These accounted for more than half the region's total number of projects.

Figure 1: Infrastructure Public-Private Partnership Projects in Developing Regions, 1985-2015

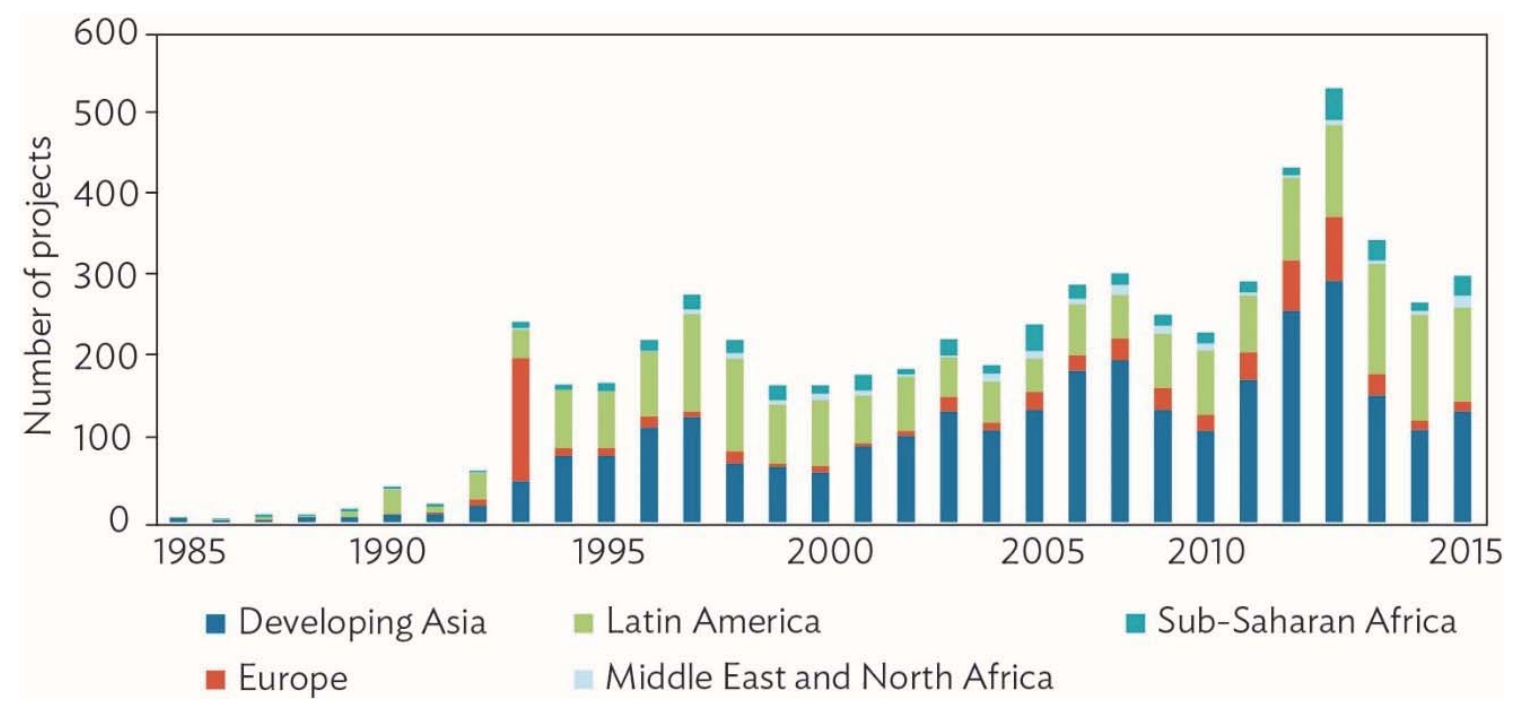

Source: World Bank. Private Participation in Infrastructure database. https://ppi.worldbank.org/data (accessed 20 March 2017). 
Figure 2: Infrastructure Public-Private Partnership Projects in Developing Asia, 1985-2015

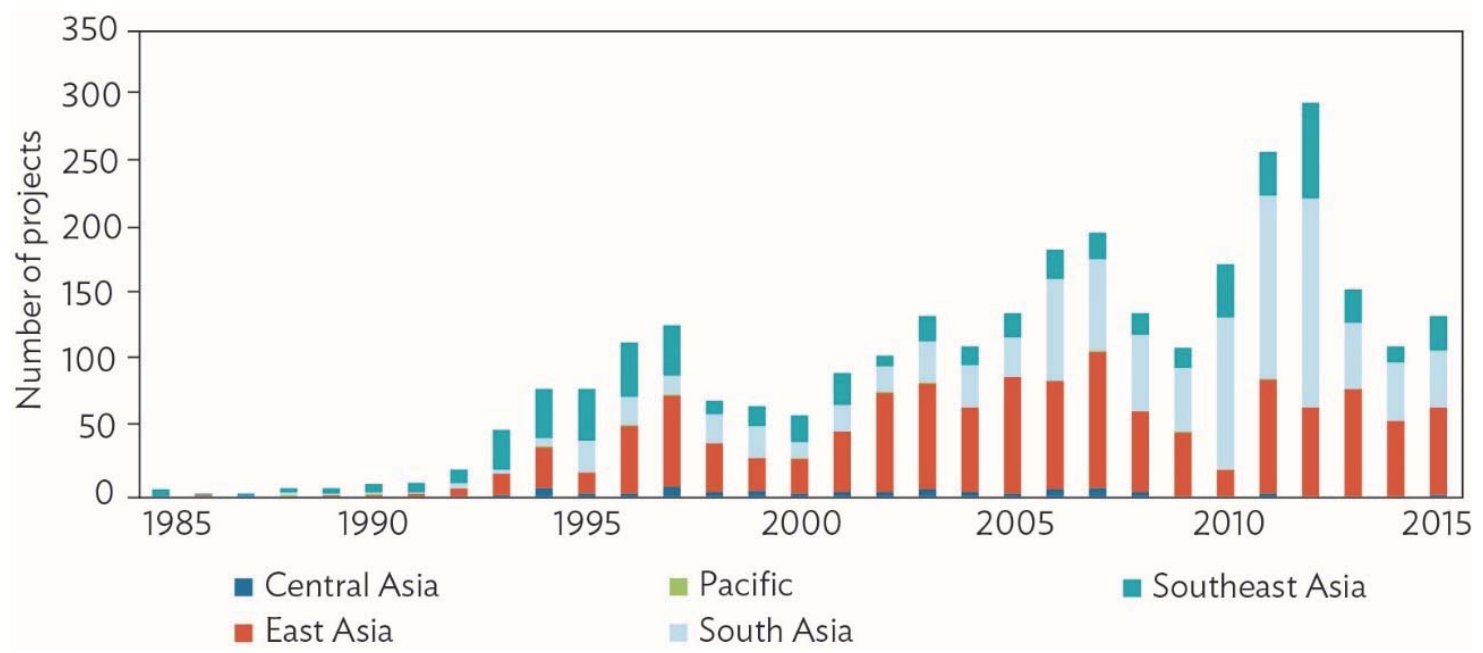

Source: World Bank. Private Participation in Infrastructure database. https://ppi.worldbank.org/data (accessed 20 March 2017).

Figure 3 breaks down developing Asia's infrastructure PPPs by sector. Most projects were in energy and transport. Energy investments have declined since 2013, an indication of the sector's growing maturity and lessening reliance on PPP support.

Figure 3: Infrastructure Public-Private Partnership Projects by Sector in Developing Asia, 1985-2015

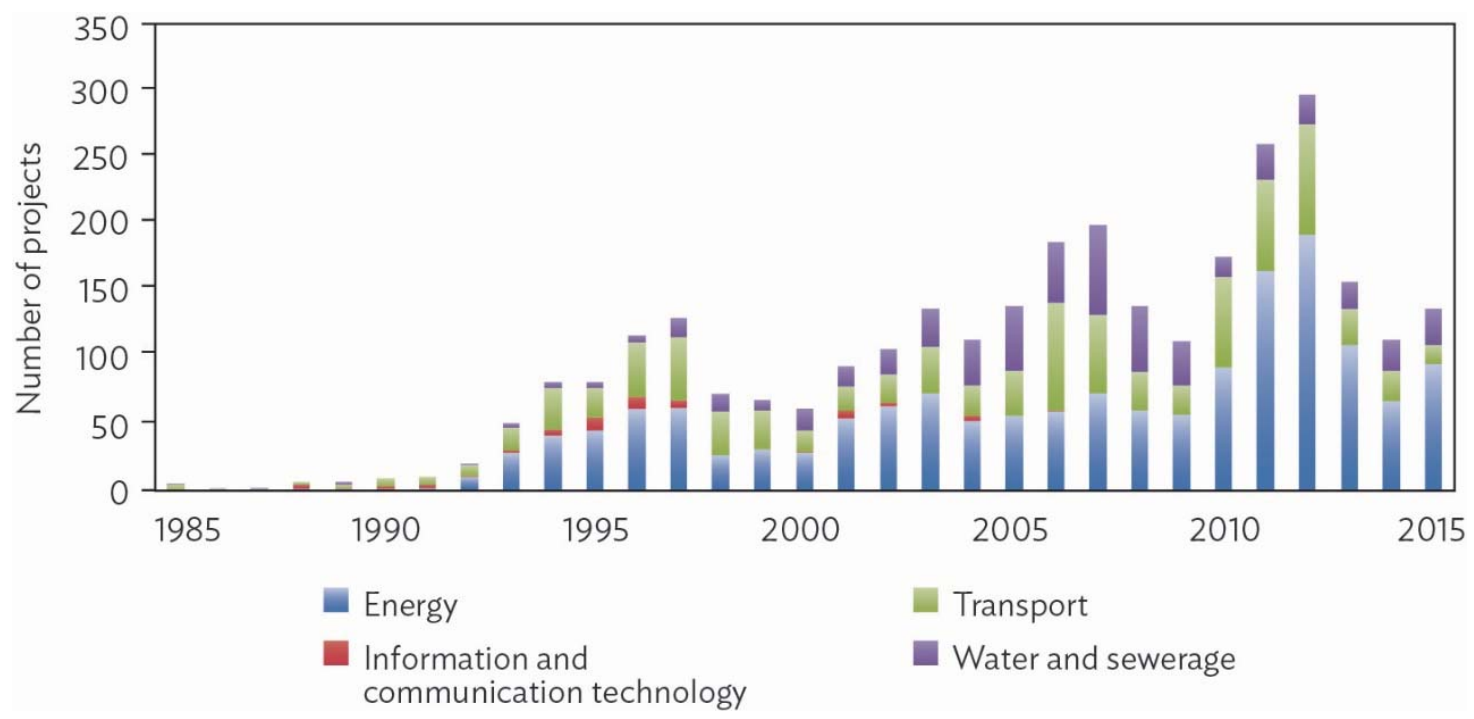

Source: World Bank. Private Participation in Infrastructure database. https://ppi.worldbank.org/data (accessed 20 March 2017). 


\section{INFRASTRUCTURE, MACROECONOMY, AND POVERTY}

One may expect that the PPP's impact mainly lies on the delivery of public infrastructure. Infrastructure is widely recognized as one of the critical factors that could determine a country's economic success. Road and rail networks, power supply, and internet connectivity improve productivity and competitiveness. They prevent bottlenecks and remove barriers, thus facilitating movements of goods and people, enhancing the means of communication, improving health and education outcomes, to name a few.

Endogenous growth models have been developed (e.g., Barro 1990, and Futagami, Morita, and Shibata 1993) to examine the impact of infrastructure on long-term production and income levels. Empirical studies also shed light on the positive association between infrastructure investment and economic growth. Aschauer's (1989) work in this area prompted others to look in more detail at the infrastructure-growth relationship by using sophisticated empirical methods, adding other variables, and using various measures of infrastructure.

Canning and Pedroni (2008) find an optimal level of infrastructure that brings long-term growth. Calderón, Moral-Benito and Servén (2015), using an infrastructure-augmented production function for output per worker to physical capital, human capital, and a synthetic measure of infrastructure, estimate a long-term output elasticity of infrastructure ranging from 0.07 to 0.10. Calderón and Servén (2010) also find robust evidence that an increase in infrastructure stock and better quality infrastructure services has positive impact on long-term growth and a negative impact on income inequality. Kodongo and Ojah (2016), in a study on Sub-Saharan countries during 2000-2011, find that spending on infrastructure and increasing access to it significantly influences economic growth and development, with the lower-income countries in the region benefiting the most.

Asia's infrastructure-growth story is much the same as for other developing regions. Seethepalli, Bramati, and Veredas (2008) find a significant positive relationship between infrastructure and economic growth in East Asia. Straub and Terada-Hagiwara (2010) find that growing infrastructure stock has had a significant and positive impact on growth in countries in East and South Asia, and the Pacific. Ismail and Mahyideen (2015) find that improvements in transport and ICT infrastructure increased trade flows and economic growth in the Asian economies that they studied.

By raising per capita GDP growth and lowering income inequality, infrastructure developmentas empirical evidence shows-helps reduce poverty (Calderón and Servén 2004). Han and Wei (2017) find from their analysis of 1960-2010 data that infrastructure helps boost economic growth, especially for low-income countries. Setboonsarng (2010) argues that investments in transport infrastructure reduce poverty indirectly through economic growth. In Indonesia, Kwon (2005) finds that good roads improve economic growth and reduces poverty in provinces.

Among studies analyzing the distributive impact of infrastructure development, Calderón and Chong (2004) and Calderón and Servén (2004) find that income inequality declines with more and better infrastructure. Calderón and Servén (2014) find positive effects of infrastructure development on income growth and, tentatively, on distributive equity. For urban areas in the People's Republic of China, Mendoza (2017) observes that certain types of infrastructure, such as waste treatment, green spaces, and energy and water projects, are associated with reductions in income inequality. 


\section{A. Public-Private Partnerships and the Macroeconomy}

There are only a few empirical studies on the economic impact of PPPs. With limited data, attribution or causality cannot be easily drawn out of macro-level analyses. Some micro-level analyses use quasiexperimental approaches to estimate the effect of infrastructure PPP projects on welfare measures, including for poverty reduction. But these evaluations do not have well-defined counterfactuals (Dintilhac, Ruiz-Nuñez, and Wei 2015).

Because not enough studies have been done on the macroeconomic impact of PPPs, mixed views emerge from the few that have been done. Using the Private Participation in Infrastructure Database, Trujillo et al. (2002) find that private sector participation in transport has a positive effect on income per capita. Using the same database, Rhee and Lee (2007) find a negative but not statistically significant coefficient on PPP investment, after controlling for public infrastructure spending. For the Republic of Korea, Kim et al. (2011) show that an increase in capital expenditure from infrastructure PPP investments expand growth by as much as $0.2 \%$ in 2008 .

Theoretical studies on public procurement show how PPPs come out as a desirable option for the delivery of infrastructure and related services relative to other modality. PPPs make optimal use of the private sector's skills, technology, and innovation that are needed throughout a project's life, especially when fiscal resources are tight (lossa and Martimort 2015, European PPP Expertise Centre 2015, de Bettignies and Ross 2004, Davies and Eustice 2005, Henckel and McKibbin 2010). Infrastructure projects done by PPPs are more likely to reach the desired level of performance. This is because contract agreements require private partners to deliver assets on time and within budget, manage project delivery, and maintain and refurbish assets (Davies and Eustice 2005).

Studies argue that PPPs guarantee value for money-broadly defined as the ability to improve the delivery of benefits relative to the associated costs across a range of alternatives. Bundling PPPs help reduce a project's life-cycle costs (Davies and Eustice 2005, Henckel and McKibbin 2010, lossa and Martimort 2015). Bundling also incentivizes private partners to design and build infrastructure at lower overall long-term costs, reduce, and hand back well-maintained assets to the government at the end of the contract.

Because of the many risks involved in infrastructure projects in general, PPP arrangements help best analyze and allocate risks to the party best placed to handle them. Risk allocation strategies in PPP contracts incentivize all parties to fulfill their contract obligations. PPPs are natural filters for eliminating infrastructure projects that can often turn out to be white elephants (Engel 2016, Henckel and McKibbin 2010). But poorly designed PPP contracts can lead to considerable costs that are borne by taxpayers. All aspects of PPPs must be carefully considered to avoid this, backed by strong and quality institutions. It is worth the effort to strengthen institutions for PPPs because doing this will have a beneficial ripple effect on other private endeavors and the general economy.

\section{B. The Channels of Public-Private Partnerships Impacts}

As well as project contexts, there are macro variables that are vital for successfully carrying out infrastructure PPP projects. Much of the recent literature on the determinants of public-private partnership activities revolve around the role of institutions. Hammami, Ruhashyankiko, and Yehoue (2006) find that less corruption and effective rule of law are associated with more PPP projects. Schomaker (2014) finds that a high degree of institutional quality is associated with stronger private sector participation in providing public services. 
Figure 4 shows the different channels through which PPPs, either as an infrastructure project or a public finance tool, can affect macroeconomic performance. When the emphasis of PPP contracts is on the quality of infrastructure-particularly delivering a project on time and maintaining it well-the infrastructure-growth link becomes stronger. lossa and Martimort (2015) note that the bundling of different phases of providing infrastructure involved in PPPs incentivizes operators to invest more in asset quality compared with traditional procurement.

The higher-level skills needed for complex PPP contracting could actually help strengthen institutions, which is deemed crucial for Asia's economic development. And the technical and institutional capacity, and good governance required for PPPs can be deployed in other public services.

Another important channel is that infrastructure PPPs free up resources for public services in human capital development and social security. Lastly, PPPs can also co-opt the private sector into national development plans through bankable infrastructure projects, since these partnerships have a huge-but so far largely untapped-potential to attract long-term savings in the form of pension, insurance, and sovereign wealth funds for infrastructure projects offering higher returns for the risk. Matching long-term savings to PPP project will help optimize resource allocation, and contribute to economic growth (Arezki et al. 2016).

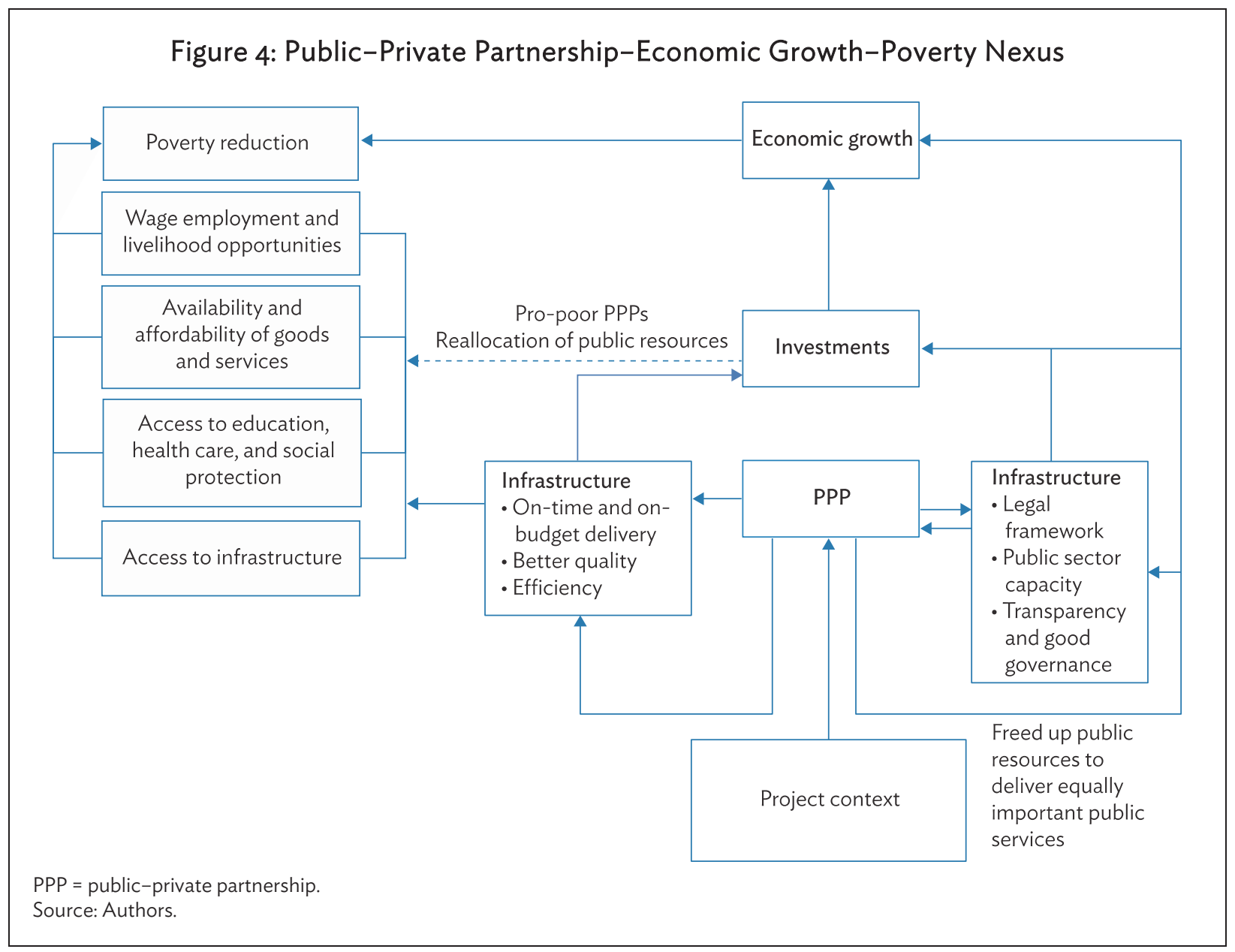


The underlying rationale for PPPs to build better quality infrastructure is a necessary condition for spurring economic growth, and eventually reach the poor by expanding wage employment and livelihood opportunities. Low-income households should have access to and can afford infrastructure services as they generally spend more on basic goods and services. Wallich (2002) notes that without both the poor are often at the mercy of more expensive alternatives for safe water and electricity. The Pro-Poor PublicPrivate Partnership or 5Ps aims to establish community-based utilities through public and private investments. Among these are renewable energy projects in underserved rural communities in Indonesia, Nepal, and the Lao People's Democratic Republic that provide affordable electricity as well as income and livelihood (UNESCAP 2014).

\section{DATA AND EMPIRICAL APPROACH}

Two general approaches are frequently used to analyze the impact of infrastructure, of which PPPs are a subset. The first is the production function, with infrastructure as a key production input; the second is cross-country growth regressions that relate economic outcomes to indicators of infrastructure, controlling for other critical growth determinants (Servén 2010).

This paper uses the second approach by estimating the following growth regression:

$$
\begin{gathered}
g_{i t}=\alpha y_{i, t-1}+\mathbf{x}_{i t}^{\prime} \beta+\varepsilon_{i t} \\
\varepsilon_{i t}=\alpha_{t}+\mu_{i}+v_{i t}
\end{gathered}
$$

where $g_{i t}$ is the real per capita GDP growth of country $i$ at year $t, y_{i, t-1}$ captures the conditional convergence using the logarithm of real per capita GDP of country $i$ at year $t-1$, and $\mathbf{x}_{i t}$ is a column vector of growth regressors, with PPP investment as percentage of GDP as the variable of interest. The disturbance term, $\varepsilon_{i t}$, has orthogonal components: the country and year fixed effects, $\mu_{i}$ and $\alpha_{t}$, and the idiosyncratic shocks, $v_{i t}$.

Depending on the availability of data, we arrive at an unbalanced panel involving 19 developing Asian economies over the period 1985-2015. Table A1 in the Appendix presents the variables used in the analysis, with their definitions and sources.

\section{A. Growth Determinants}

In relation to the neoclassical growth theories, the initial level of income assesses evidence of conditional convergence across countries (Barro and Sala-i-Martin 2004). This concept predicts that an economy's growth rate tends to slow as it approaches the steady state growth. A negative partial correlation is therefore expected between economic growth and initial level of income; that is, growth tends to be higher for economies that started at lower per capita income (Pritchett and Summers 2014).

Human capital development matters to growth, especially in the long term. Trade openness, the export-led growth model and, arguably, the significance of globalization are well-researched growth determinants. Inflation primarily affects growth through consumption and production. But the overall effect of inflation tends to be ambiguous because key economic actors behave differently with higher general prices. Here, households tend to consume less, but producers have an incentive to produce.

The role of government can negatively affect economic growth if it distorts private sector decisions and mismanages public finance (Barro and Sala-i-Martin 2004). A higher value of the 
government consumption ratio leads to a lower steady-state level of output per effective worker and, hence, to a lower growth rate for given values of state variables. Financial development is another wellresearched determinant of economic growth. Economies with developed financial systems could experience higher growth in relation to their ability to raise funds to support economic activities, notwithstanding their capacity to channel funds for better use.

\section{B. Public-Private Partnership Investment Data: Sources, Issues, and Adjustments}

The PPP investment data for developing Asia are taken from the Private Participation in Infrastructure Database. The database records contractual arrangements for public infrastructure projects in low- and middle-income countries (based on World Bank classification) that have reached financial closure in which private parties assume operating risks. The database covers projects in energy, telecommunications, transport, and water and sewerage sectors contracted under management or lease contracts, concessions, greenfield projects, or divestitures. Because the database compiles only PPPs for low- and middle-income economies, PPP investment in Asia's high-income economies, such as the Republic of Korea and Singapore, are taken from country sources.

The investment amounts in the database, and the data gathered from country sources, represent the total investment commitments agreed at the financial closure of a PPP project. Because of this, the PPP investments captured in this study varies with actual PPP investments over a project's life cycle. Thus, results using this data should be interpreted as being in the upper bound of the size of PPPs (Romp and de Haan 2005). Kappeler and Nemoz (2010) and Romp and de Haan (2005) tackle the measurement issue by spreading the amount of investment commitment equally over certain years. Following Kappeler and Nemoz (2010), we spread the total transaction amounts over 5 years to arrive at annualized PPP investment. ' To be comparable across years, we convert the PPP investment series to constant 2011 international dollars.

Another data issue is risk of incompleteness and inaccuracies. This particularly applies to the Private Participation in Infrastructure Database, which draws its information exclusively from publicly available sources, and assumes all sources are reliable.

\section{Channels for Macroeconomic Impact and Poverty Reduction}

To validate propositions in the framework identifying channels through which PPPs benefit the overall economy, we run additional empirical exercises. For this, we follow the specification adopted by Cerra et al. (2016) that tries to identify the factors explaining differences in the levels and quality of infrastructure across countries in Latin America and the Caribbean. The specification is as follows:

$$
\begin{gathered}
\operatorname{Infra}_{i t}=\alpha+\mathbf{x}_{i t}^{\prime} \beta+\varepsilon_{i t} \\
\varepsilon_{i t}=\alpha_{t}+\mu_{i}+v_{i t}
\end{gathered}
$$

where Infra $\mathrm{ft}_{\text {it }}$ are measures of infrastructure access and quality including (i) access to electricity (\% of total population), (ii) access to electricity (\% of rural population), (iii) telephone subscriptions per 100 people, (iv) mobile subscriptions per 100 people, (v) improved water source (\% of total population), (vi) improved water source (\% of rural population), (vii) improved water sanitation (\% of total population),

1. This is also adopted by the International Monetary Fund in its estimation of PPP investment for its Investment and Capital Stock Dataset for 1985-2015. 
(viii) improved water sanitation (\% of rural population), (ix) road quality score, and ( $x$ ) overall infrastructure quality score. The column vector of independent variables is given by $\mathbf{x}_{i t}$. We are interested in the variable, PPP investment as percentage of GDP, to determine how PPPs potentially affect both access and quality of infrastructure services, which are identified as channels through which PPPs can deliver macroeconomic benefits. The disturbance term, $\varepsilon_{i t}$, has orthogonal components: the country and year fixed effects, $\mu_{i}$ and $\alpha_{t}$, and the idiosyncratic shocks, $v_{i t}$.

We also analyze variation in employment that may be associated with fluctuations in PPP investments. Employment created in the delivery of PPP projects could directly affect poverty. Gutierrez et al. (2007) note how sectoral productivity and employment pattern may hold important implications in reducing poverty. For this, we estimate the following equation with employment-share growth in major economic sectors as the dependent variable:

$$
\begin{gathered}
\text { Employ }_{i t}=\alpha+\mathbf{x}_{i t}^{\prime} \beta+\varepsilon_{i t} \\
\varepsilon_{i t}=\alpha_{t}+\mu_{i}+v_{i t}
\end{gathered}
$$

The column vector of independent variables, $\mathbf{x}_{i t}$, include PPP investment (\% of GDP), real per capita GDP, education expenditure (\% of GDP), primary completion rate, minimum wage, and share of the working-age population. And $\varepsilon_{i t}$ denotes the disturbance term.

In addition to analyzing how social infrastructure PPPs affect development outcomes, we gathered investment data on these projects from the IJGlobal database from 2002 to 2017, and estimated their effect on select education outcomes.

\section{EMPIRICAL FINDINGS}

We find evidence that PPPs have positive macroeconomic impacts. This could be attributed to findings in the results that PPPs help improve access to and the quality of infrastructure services. As an extension of its impact on economic growth, PPPs could be important tools for poverty eradication efforts in developing Asia.

\section{A. Public-Private Partnership Investment Booms}

The uneven quality of the data complicate our regression analysis. To overcome data issues on PPP investment, we conduct an event analysis to look at what happened in the years after-relative to the years before-a particular event. As Warner (2014) puts it, this type of quantitative exercise is a simple way of establishing the stylized facts about the macroeconomic conditions surrounding an event.

Here, we see that an investment boom-PPP investment (\% of GDP) grows for 3 consecutive years -is associated with higher growth. Figure 5 shows how real per capita GDP growth is higher after an investment boom relative to the period before it. The positive relationship between PPPs and economic growth could be attributed to the huge capital involved in these projects. Shediac et al. (2008) note large infrastructure projects generate employment in the short and long term, and crowd in private investment. However, the corresponding growth impact in this analysis is rather short-lived. The difference in economic growth reaches more than $2 \%$, but stabilizes 4 years later. Even so, this does not put the long-term growth impacts of PPPs in question, given the expected productivity improvements associated with better infrastructure. 
Figure 5: Real Per Capita Gross Domestic Product Growth Before and After a PPP Investment Boom

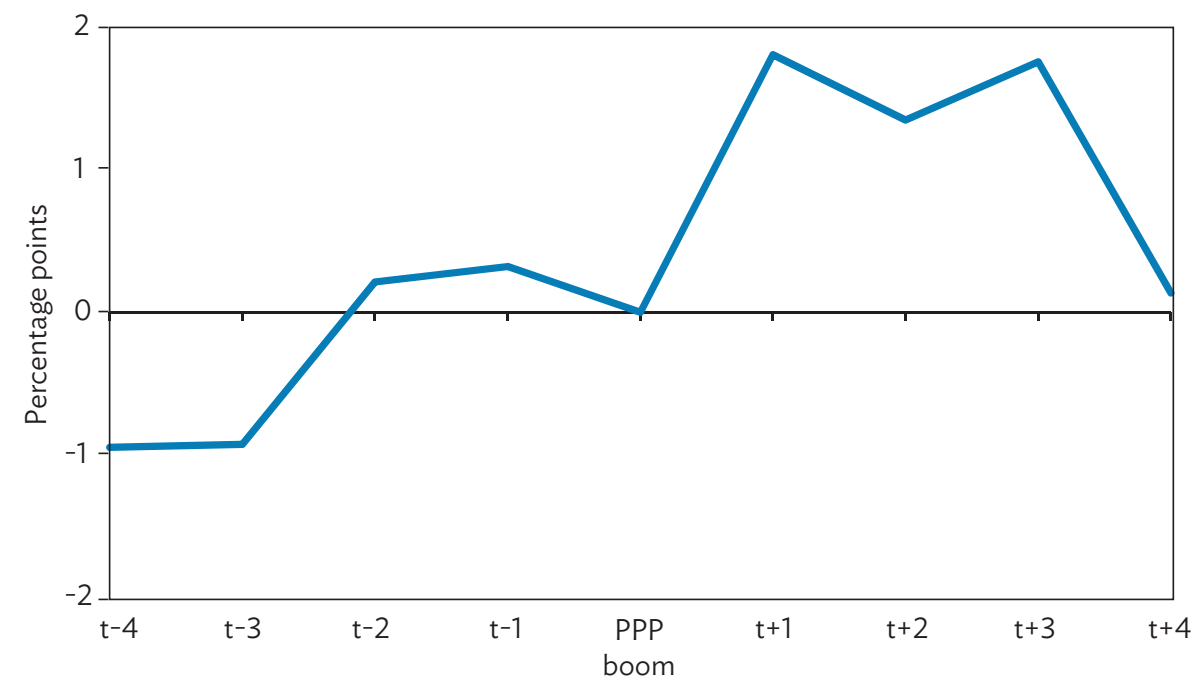

PPP = public-private partnership

Source: Authors.

\section{B. Public-Private Partnership Readiness}

Instead of using popular measures of PPPs, such as amount of investment and number of projects, we examine how economic growth relates with capabilities to handle the complexity of these projects for preparation, procurement, and contract management. These measures capture the institutional and capacity improvements that could be attributed to PPP practices. Figure 6 shows the positive relationship between economic growth and government capabilities to handle PPPs in different areas.

Figure 6: Average Real per Capita Gross Domestic Product Growth and Capabilities to Manage Public-Private Partnerships
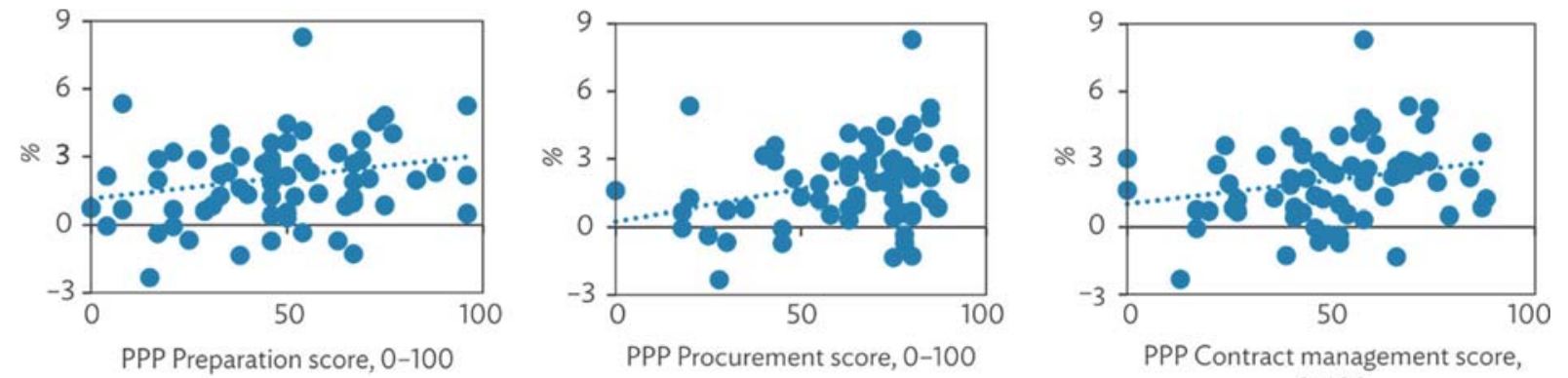

$0-100$

PPP = public-private partnership.

Source: World Bank. 2016. Benchmarking Public-Private Partnerships Procurement. Washington, DC. 
Figure 7: Public-Private Partnership Readiness Score in Asia and the Pacific, 2014

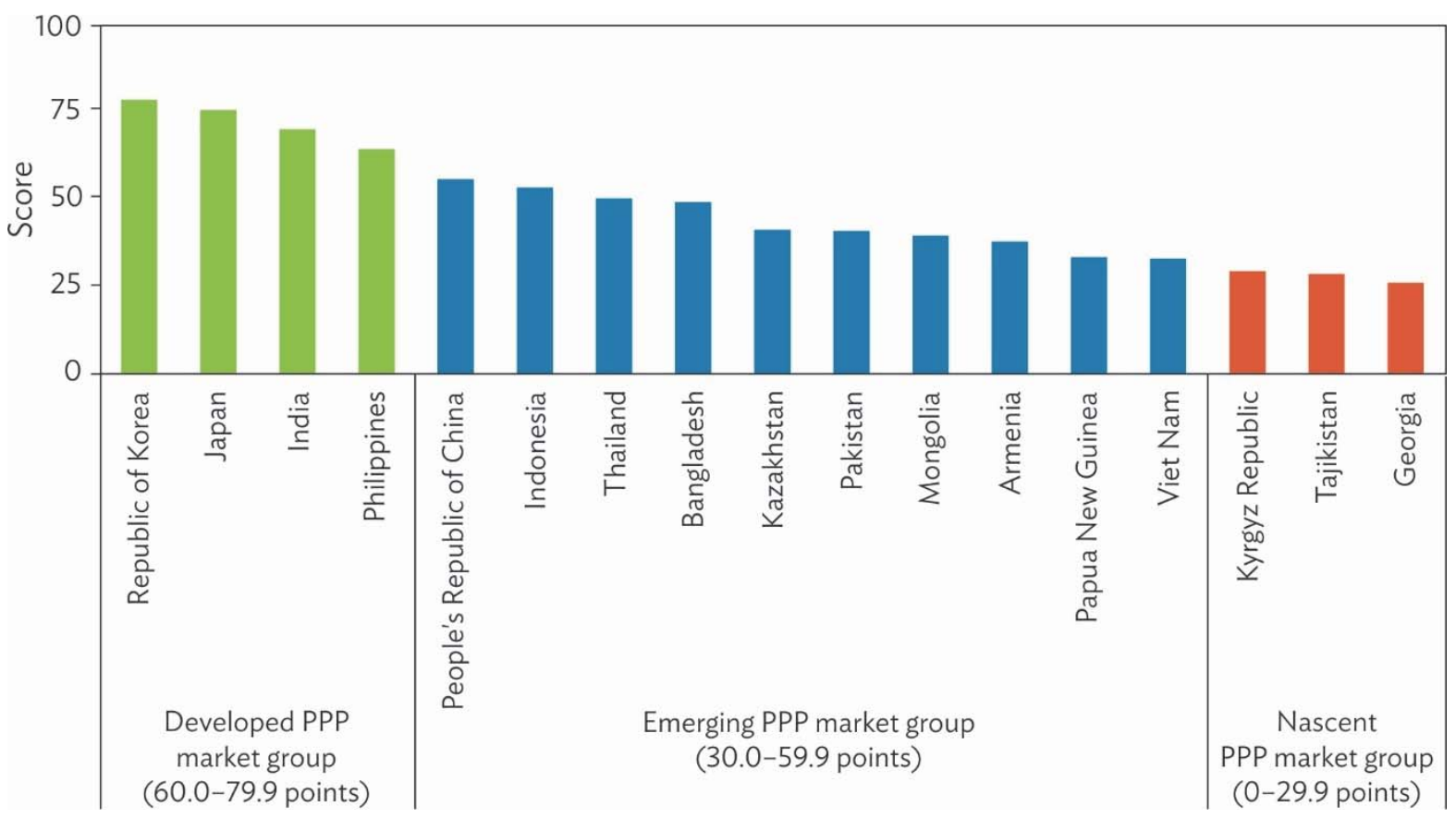

PPP = public - private partnership

Source: The Economist Intelligence Unit. 2014. The 2014 Infrascope Index and Report. London.

Implementing PPP projects is an opportunity to reexamine regulatory and policy arrangements to improve governance and public sector capacity. Taipei,China, learning from its first experience with a large PPP project for a high-speed rail system, passed legislation in 2000 to promote private participation in infrastructure projects, which became the institutional framework for PPPs in that economy.

Developing economies in Asia and the Pacific have significantly improved their capacity to handle PPP projects (Figure 7). Their regulatory and institutional frameworks, investment climate, and financial facilities are increasingly being geared toward promoting PPPs. And this may have led to the growing use of PPPs for infrastructure in some countries.

\section{Public-Private Partnership Investments and Real GDP growth}

Table 1 shows the results of equation 1 for developing Asia. The coefficient of PPP investment (\% of GDP) is found consistently positive and statistically significant across all variations of the baseline model (column 1). 
Table 1: Public-Private Partnership and Economic Growth in Developing Asia

\begin{tabular}{|c|c|c|c|c|c|}
\hline Variable & (1) & (2) & (3) & (4) & (5) \\
\hline \multirow[t]{2}{*}{ PPP investment ( $\%$ of GDP) } & $0.340^{*}$ & $0.342^{*}$ & $0.357^{*}$ & $0.337^{*}$ & $0.359^{*}$ \\
\hline & $(0.197)$ & $(0.198)$ & $(0.199)$ & $(0.198)$ & $(0.198)$ \\
\hline \multirow[t]{2}{*}{ Fiscal balance (\% of GDP) } & & -0.068 & -0.048 & -0.061 & -0.040 \\
\hline & & $(0.105)$ & $(0.107)$ & $(0.106)$ & $(0.107)$ \\
\hline \multirow[t]{2}{*}{ PPP * Fiscal condition dummy } & & -7.212 & -6.089 & -7.283 & -7.026 \\
\hline & & $(13.510)$ & $(13.551)$ & $(13.527)$ & $(13.459)$ \\
\hline \multirow[t]{2}{*}{ Corruption index, WGI } & & & 2.197 & & \\
\hline & & & $(2.134)$ & & \\
\hline \multirow[t]{2}{*}{ Rule of law, WGI } & & & & 1.668 & \\
\hline & & & & $(2.074)$ & \\
\hline \multirow[t]{2}{*}{ Government effectiveness, WGI } & & & & & 3.330 \\
\hline & & & & & $(2.291)$ \\
\hline \multirow[t]{2}{*}{ Conditional convergence hypothesis } & $-17.541^{* * *}$ & $-17.325^{* * *}$ & $-17.733^{* * *}$ & $-17.647^{* * *}$ & $-18.489^{* * *}$ \\
\hline & (3.114) & $(3.347)$ & $(3.370)$ & $(3.375)$ & $(3.429)$ \\
\hline \multirow[t]{2}{*}{ Inflation } & $0.183^{* *}$ & $0.192^{* *}$ & $0.193^{* *}$ & $0.198^{* *}$ & $0.219^{* * *}$ \\
\hline & $(0.078)$ & $(0.080)$ & $(0.080)$ & $(0.080)$ & $(0.081)$ \\
\hline \multirow[t]{2}{*}{ Primary completion rate } & 0.005 & 0.003 & 0.004 & -0.005 & 0.013 \\
\hline & $(0.042)$ & $(0.044)$ & $(0.044)$ & $(0.045)$ & $(0.044)$ \\
\hline \multirow[t]{2}{*}{ Population growth } & -1.249 & -1.136 & -1.220 & -1.333 & -1.499 \\
\hline & $(0.879)$ & $(0.898)$ & $(0.901)$ & $(0.931)$ & $(0.929)$ \\
\hline \multirow[t]{2}{*}{ Private credit ( $\%$ of GDP), in logs } & 0.436 & 0.521 & 0.534 & 0.572 & 0.525 \\
\hline & $(1.015)$ & $(1.042)$ & $(1.041)$ & $(1.045)$ & $(1.038)$ \\
\hline \multirow[t]{2}{*}{ Gini coefficient } & 3.268 & 2.849 & 2.091 & 2.569 & 2.832 \\
\hline & $(12.182)$ & $(12.261)$ & $(12.280)$ & $(12.281)$ & $(12.214)$ \\
\hline \multirow{2}{*}{$\begin{array}{l}\text { Government consumption } \\
(\% \text { of GDP), in logs }\end{array}$} & -3.094 & -3.166 & $-3.510^{*}$ & $-3.604^{*}$ & $-3.272^{*}$ \\
\hline & $(1.904)$ & $(1.939)$ & $(1.968)$ & $(2.017)$ & $(1.933)$ \\
\hline \multirow[t]{2}{*}{ Trade ( $\%$ of GDP), in logs } & 0.930 & 0.577 & 0.657 & 0.670 & 0.484 \\
\hline & $(1.640)$ & $(1.817)$ & $(1.818)$ & $(1.823)$ & $(1.811)$ \\
\hline \multirow[t]{2}{*}{ Public capital stock, annual growth } & $18.400^{* * *}$ & $19.095^{* * *}$ & $19.201^{* * *}$ & $19.641^{* * *}$ & $20.672^{* * *}$ \\
\hline & $(6.849)$ & $(7.030)$ & $(7.030)$ & $(7.072)$ & $(7.087)$ \\
\hline \multirow[t]{2}{*}{ Constant } & $133.520^{* * *}$ & $133.382^{* * *}$ & $138.293^{* * *}$ & $137.965^{* * *}$ & $143.214^{* * *}$ \\
\hline & $(25.251)$ & $(27.903)$ & $(28.302)$ & $(28.512)$ & $(28.607)$ \\
\hline Observations & 187 & 187 & 187 & 187 & 187 \\
\hline$R^{2}$ value & 0.452 & 0.455 & 0.459 & 0.457 & 0.463 \\
\hline Number of countries & 19 & 19 & 19 & 19 & 19 \\
\hline
\end{tabular}

GDP = gross domestic product, $\mathrm{PPP}=$ public-private partnership, $\mathrm{WGI}=$ World Governance Indicators. Note: Dependent variable is real per capita GDP growth. Standard errors in parentheses. *** $p<0.01,{ }^{* *} p<0.05,{ }^{*} p<0.1$. Source: Authors' estimates. 
The baseline model is adjusted to check for possible nonlinearity of the relationship between PPPs and economic growth. To examine whether the use of PPPs as a procurement modality rises during periods of severe fiscal constraint, we add an interaction term of PPP with a dummy variable that takes the value of 1 if at year $t$, country $i$ records a fiscal deficit of more than 10\% of its GDP, indicating severity of fiscal constraint, otherwise it takes the value of 0 . Column 2 presents the result, which is not statistically significant. In fact, it even returns a negative coefficient that diminishes the growth contribution of PPP investment. In columns 3-5, we add institutional variables (corruption, rule of law, and government effectiveness) in the baseline model to control for heterogeneity in institutional quality and characteristics. Their addition does not alter the significance of the coefficient before PPP investment (\% of GDP). We note, however, the potential upward bias of the coefficient before the PPP ratio due to the reverse causality, which also applies in Table $2 .^{2}$

\section{Infrastructure Access and Quality}

Table 2 suggests that as well as increasing access to infrastructure, PPP projects provide incentives for the private partner to enhance the quality of infrastructure services-if, that is, contracts are properly crafted. Coefficients of the variable of interest are found positive and significant across selected indicators of access to infrastructure services, such as energy, telecommunications, water supply, and sanitation. Access to telecommunication, particularly mobile phones, shows higher coefficients than fixed-line telephone and broadband subscriptions. This is in line with findings of a general trend of increasing telephone connections, and advances in ICT because of private sector participation (John et al. 2015). Infrastructure PPPs are also helping to tackle developing Asia's rapid urbanization, which requires better access to essential infrastructure amid growing populations.

2 PPPs are more likely to be undertaken when the economy is in good shape. The need to prevent infrastructure backlogs and economic overheating during a series of economic growth may favor a PPP mode of infrastructure provision. 


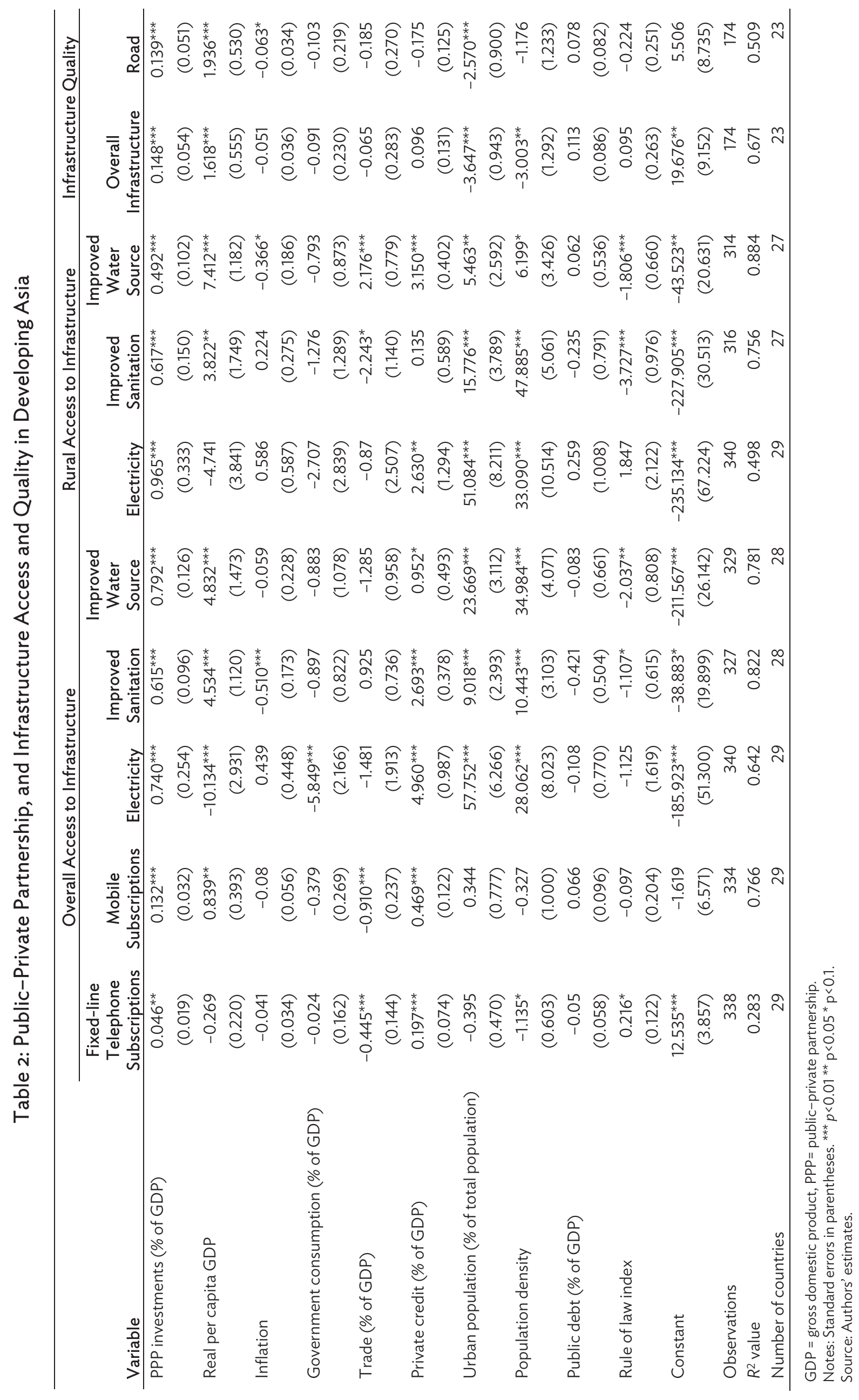




\section{Table 3: Effect of Increasing Public-Private Partnership Investments as Percentage of GDP in Developing Asia}

\begin{tabular}{|c|c|c|c|}
\hline Variable & $\begin{array}{l}\text { PPP Ratio } \\
\text { Increase to } 1 \%\end{array}$ & $\begin{array}{l}\text { PPP Ratio } \\
\text { Increase to } 2 \%\end{array}$ & $\begin{array}{c}\text { PPP Ratio } \\
\text { Increase to } 3 \%\end{array}$ \\
\hline Increase in real per capita GDP growth (percentage point) & 0.1 & 0.3 & 0.4 \\
\hline $\begin{array}{l}\text { Reduction in the number of people without electricity } \\
\text { (million) }\end{array}$ & 14 & 41 & 69 \\
\hline $\begin{array}{l}\text { Reduction in the number of people without proper } \\
\text { sanitation (million) }\end{array}$ & 16 & 47 & 78 \\
\hline $\begin{array}{l}\text { Reduction in the number of people without safe drinking } \\
\text { water (million) }\end{array}$ & 12 & 36 & 60 \\
\hline
\end{tabular}

GDP = gross domestic product, $\mathrm{PPP}=$ public-private partnership.

Note: Marginal effect is estimated using the 2015 average PPP ratio; that is, $0.5 \%$ of GDP.

Source: Authors' estimates.

Table 3 shows the estimated effect of increasing PPP infrastructure investments in developing Asia. Increasing PPP investments as a percentage of GDP is associated with higher quality infrastructure services, reflecting the innovation and efficiency gains that partnering with the private sector can deliver. Consequently, improved access and quality, alongside public sector reforms to strengthen PPP processes, can deliver additional economic growth. Increasing PPP investments relative to GDP would, on average, result in higher real per capita GDP growth of 0.1 percentage point, keeping other factors constant.

\section{CONCLUSION AND POLICY RECOMMENDATIONS}

Despite the strides made in building infrastructure in developing Asia, improving access and quality remains a huge agenda. Over 400 million people live without electricity in the region, 300 million without access to safe drinking water, and 1.5 billion lack basic sanitation. Developing Asia needs to invest $\$ 1.7$ trillion in infrastructure every year to maintain its growth momentum, eradicate poverty, and respond to the challenges of climate change (ADB 2017).

Traditional procurement is still by far the main way for developing infrastructure in the region, with more than $90 \%$ of infrastructure spending coming from public funds. This is equivalent to $5.1 \%$ of GDP annually. Private sector spending in infrastructure is just $0.4 \%$ of GDP (ADB 2017). Public funds and support from multilateral development banks will not be sufficient to meet the region's demand for infrastructure. But partnering with the private sector could potentially fill the financing gap. PPPs have proved themselves to be the most viable way to involve the private sector in building and operating public infrastructure, including social infrastructure. So far, the increased use of PPPs to finance, build, and operate infrastructure in the region is concentrated in just a few countries, notably India and the PRC. But PPPs are starting to gain traction in other countries (Appendix Table A2).

This paper shows the complex path through which PPPs, either as an infrastructure project or a public finance tool, can potentially bring macroeconomic benefits. And we identified four direct channels to do this, based on literature reviews and country experiences. Through PPPs, the infrastructure-growth link becomes stronger, especially when partnership arrangements emphasize quality of infrastructure service, better maintenance, and delivering projects on time and within budget. 
Public sectors need to strengthen their institutional capacity to carry out PPPs, and the legal and regulatory frameworks for PPP processes. And transparency and good governance must be second nature in the practice of PPPs. Improvements on all these fronts would enable developing Asian economies to free up more public resources and devote more effort to other public services where the needs are pressing, such as those targeting the poor (social protection through cash transfers, for example).

Further, PPPs can be important vehicles to involve the private sector in attaining national development goals. PPP has vast potential to unlock savings in long-horizon investment vehicles (e.g., pension funds, insurance funds, and sovereign wealth funds) and channel it to long-horizon infrastructure projects.

The empirical results of this analysis suggest that PPPs are associated with improved access to and quality of infrastructure services, and so affect economic growth and other development outcomes (Appendix Tables A3 and A4). While the macroeconomic impacts of PPPs may differ country by country, they are mainly positive. But this optimism is conditional on considerable institutional improvements for PPPs being made, especially on contracts arrangements. Every PPP legal and regulatory frameworks must ensure efficient competitive arrangements to avoid bilateral monopolies, and ensure that social welfare is the overall goal for infrastructure PPPs regardless of the different priorities and needs of public and private sector partners.

Countries across the region have significantly improved their handling of infrastructure PPP projects, though most countries are at the developing stage. The exceptions are India, the Philippines, and the Republic of Korea (The Economist Intelligence Unit 2014). To enhance readiness, economies need to develop required technical expertise and capacity to deliver complex PPP projects. A World Bank (2016) study assessing how well governments of 82 economies prepare, procure, and implement PPP projects found most developing Asian economies lagged behind countries in the Organisation for Economic Co-operation and Development, Latin America, and Europe. Further improvements are needed for PPP project preparation and procurement, and for dealing with unsolicited project proposals. If not tackled, PPPs may be seen as an inferior choice to traditional procurement, making it harder for these partnerships to be more widely adopted in developing Asia and undermining their potential to deliver macroeconomic benefits. 


\section{APPENDIX}

Table A1: Variables, Definitions and Data Sources for the Analysis

\begin{tabular}{|c|c|c|}
\hline Variable & Definition & Data Source \\
\hline $\begin{array}{l}\text { Initial level of real } \\
\text { per capita GDP }\end{array}$ & $\begin{array}{l}\text { Lagged real per capita GDP (in constant } \\
2010 \text { dollars), expressed in logs }\end{array}$ & $\begin{array}{l}\text { World Development Indicators Database, } \\
\text { World Bank }\end{array}$ \\
\hline Population growth & Annual growth of total population & World Development Indicators Database \\
\hline $\begin{array}{l}\text { Education } \\
\text { (human capital) }\end{array}$ & Primary completion rate & World Development Indicators Database \\
\hline Trade openness & $\begin{array}{l}\text { Trade (exports plus imports) as a } \\
\text { percentage of GDP, expressed in logs }\end{array}$ & World Development Indicators Database \\
\hline Inflation rate & $\begin{array}{l}\text { CPI inflation rate. Transformed to smoothen } \\
\text { hyperinflation episodes following Calderón } \\
\text { and Servén's (2010) computation: } \\
\log \left((1+i r)^{*} 100\right) \text {, where ir is the inflation rate. }\end{array}$ & World Development Indicators Database \\
\hline Income inequality & Gini coefficient & PovcalNet, World Bank \\
\hline Financial development & $\begin{array}{l}\text { Domestic credit to private sector as } \\
\text { percentage of GDP, expressed in logs } \\
\text { Liquid liabilities as percentage of GDP, } \\
\text { expressed in logs }\end{array}$ & $\begin{array}{l}\text { Global Financial Development Database, } \\
\text { World Bank; International Financial } \\
\text { Statistics, International } \\
\text { Monetary Fund }\end{array}$ \\
\hline Government size & $\begin{array}{l}\text { General government consumption } \\
\text { expenditure as percentage of GDP, } \\
\text { expressed in logs }\end{array}$ & World Development Indicators Database \\
\hline Employment in agriculture & $\begin{array}{l}\text { Percentage of total employment, expressed } \\
\text { in logs }\end{array}$ & World Development Indicators Database \\
\hline Employment in industry & $\begin{array}{l}\text { Percentage of total employment, expressed } \\
\text { in logs }\end{array}$ & World Development Indicators Database \\
\hline Employment in services & $\begin{array}{l}\text { Percentage of total employment, expressed } \\
\text { in logs }\end{array}$ & World Development Indicators Database \\
\hline Access to electricity & Percentage of population, expressed in logs & World Development Indicators Database \\
\hline $\begin{array}{l}\text { Access to improved } \\
\text { water source }\end{array}$ & Percentage of population, expressed in logs & World Development Indicators Database \\
\hline $\begin{array}{l}\text { Access to improved } \\
\text { sanitation }\end{array}$ & Percentage of population, expressed in logs & World Development Indicators Database \\
\hline $\begin{array}{l}\text { Fixed telephone } \\
\text { subscriptions }\end{array}$ & Per 100 people, expressed in logs & World Development Indicators Database \\
\hline $\begin{array}{l}\text { Mobile cellular } \\
\text { subscriptions }\end{array}$ & Per 100 people, expressed in logs & World Development Indicators Database \\
\hline $\begin{array}{l}\text { Fixed broadband } \\
\text { subscriptions }\end{array}$ & Per 100 people, expressed in logs & World Development Indicators Database \\
\hline Secondary enrollment rate & $\begin{array}{l}\text { Percentage of population at official } \\
\text { secondary education age }\end{array}$ & World Development Indicators Database \\
\hline
\end{tabular}


18 | Appendix

Table A1 continued

\begin{tabular}{|c|c|c|}
\hline Variable & Definition & Data Source \\
\hline Minimum wage & $\begin{array}{l}\text { Statutory nominal gross monthly minimum } \\
\text { wage or lowest wage that employers are } \\
\text { legally obliged to pay employees, in national } \\
\text { currency }\end{array}$ & $\begin{array}{l}\text { International Labour Organization Statistica } \\
\text { Database }\end{array}$ \\
\hline $\begin{array}{l}\text { PPP investments in } \\
\text { education }\end{array}$ & $\begin{array}{l}\text { PPP investment (million US dollars), } \\
\text { expressed in logs }\end{array}$ & Infrastructure Journal (IJGlobal) database \\
\hline $\begin{array}{l}\text { Public education } \\
\text { expenditure }\end{array}$ & Percentage of GDP, expressed in logs & World Development Indicators Database \\
\hline Health expenditure & Percentage of GDP, expressed in logs & World Development Indicators Database \\
\hline $\begin{array}{l}\text { Urban and rural } \\
\text { population }\end{array}$ & $\begin{array}{l}\text { Percentage of total population, expressed in } \\
\text { logs }\end{array}$ & World Development Indicators Database \\
\hline Population density & $\begin{array}{l}\text { People per square kilometer of land area, } \\
\text { expressed in logs }\end{array}$ & World Development Indicators Database \\
\hline Primary completion rate & $\begin{array}{l}\text { Percentage of students completing the last } \\
\text { year of primary school }\end{array}$ & World Development Indicators Database \\
\hline $\begin{array}{l}\text { Secondary completion } \\
\text { rate }\end{array}$ & $\begin{array}{l}\text { Percentage of students completing the last } \\
\text { year of secondary school }\end{array}$ & World Development Indicators Database \\
\hline
\end{tabular}

$\mathrm{CPI}=$ consumer price index, $\mathrm{GDP}=$ gross domestic product, $\mathrm{PPP}=$ public-private partnership, $\mathrm{US}=$ United States .

Note: World Development Indicators data from 2016.

Source: Authors.

\section{Table A2: Public-Private Partnership Investment Ratio to Total Infrastructure Investment in 18 Developing Asian Economies, 2011}

\begin{tabular}{lccc}
\hline Country & $\begin{array}{c}\text { Total } \\
\text { Infrastructure } \\
\text { Investment } \\
(\% \text { of GDP) }\end{array}$ & $\begin{array}{c}\text { PPP Investment } \\
(\% \text { of GDP) }\end{array}$ & $\begin{array}{c}\text { Derived PPP Ratio to } \\
\text { Total Infrastructure } \\
\text { Investment }(\%)\end{array}$ \\
\hline Armenia & 3.7 & 1.2 & 32.5 \\
Bangladesh & 2.6 & 0.0 & 1.6 \\
Bhutan & 8.0 & 2.1 & 26.1 \\
China, People's Republic of & 6.3 & 0.1 & 1.0 \\
Fiji & 3.8 & 0.0 & 0.0 \\
Georgia & 4.3 & 0.5 & 12.5 \\
India & 5.3 & 1.5 & 28.6 \\
Indonesia & 2.6 & 0.4 & 14.2 \\
Korea, Republic of & 2.5 & 0.6 & 25.2 \\
Mongolia & 2.1 & 0.0 & 0.0 \\
Nepal & 2.3 & 0.4 & 15.3 \\
Pakistan & 2.1 & 0.6 & 29.0 \\
Philippines & 2.4 & 0.7 & 30.4 \\
Singapore & 1.4 & 0.0 & 2.1 \\
Sri Lanka & 4.9 & 0.6 & 13.1 \\
Thailand & 1.5 & 0.3 & 18.5 \\
Viet Nam & 5.7 & 0.7 & 12.8 \\
\hline
\end{tabular}

$\mathrm{GDP}=$ gross domestic product, $\mathrm{PPP}=$ public-private partnership.

a Asian Development Bank. 2017. Meeting Asia's Infrastructure Needs. Manila.

b World Bank, Private Participation in Infrastructure database; Respective agencies for the Republic of Korea and Singapore.

Source: Authors' calculation. 
Table A3: Public-Private Partnership and Sectoral Employment in Developing Asia

\begin{tabular}{|c|c|c|c|c|c|c|}
\hline Variable & $\begin{array}{l}\text { Employment } \\
\text { Growth in } \\
\text { Agriculture }\end{array}$ & $\begin{array}{l}\text { Employment } \\
\text { Growth in } \\
\text { Industry }\end{array}$ & $\begin{array}{l}\text { Employment } \\
\text { Growth in } \\
\text { Services }\end{array}$ & $\begin{array}{l}\text { Employment } \\
\text { Growth in } \\
\text { Agriculture }\end{array}$ & $\begin{array}{l}\text { Employment } \\
\text { Growth in } \\
\text { Industry }\end{array}$ & $\begin{array}{c}\text { Employment } \\
\text { Growth in } \\
\text { Services }\end{array}$ \\
\hline \multirow[t]{2}{*}{ PPP investments (\% GDP) } & -0.055 & $0.080^{* *}$ & 0.053 & & & \\
\hline & $(0.041)$ & $(0.036)$ & $(0.034)$ & & & \\
\hline \multirow{3}{*}{$\begin{array}{l}\text { PPP investments in ICT } \\
\text { (\% of GDP) }\end{array}$} & & & & & & \\
\hline & & & & -0.144 & -0.221 & -0.222 \\
\hline & & & & $(0.262)$ & $(0.268)$ & $(0.254)$ \\
\hline \multirow[t]{2}{*}{$\begin{array}{l}\text { PPP investments in water } \\
\text { (\% of GDP) }\end{array}$} & & & & -0.155 & 0.055 & $0.190^{* *}$ \\
\hline & & & & $(0.093)$ & $(0.095)$ & $(0.090)$ \\
\hline \multirow[t]{2}{*}{$\begin{array}{l}\text { PPP investments in energy } \\
\text { (\% of GDP) }\end{array}$} & & & & $-0.152^{* *}$ & $0.152^{* *}$ & 0.022 \\
\hline & & & & $(0.068)$ & $(0.069)$ & $(0.066)$ \\
\hline \multirow{3}{*}{$\begin{array}{l}\text { PPP investments in transport } \\
\text { (\% of GDP) }\end{array}$} & & & & & & \\
\hline & & & & $0.336^{* * *}$ & -0.041 & -0.094 \\
\hline & & & & $(0.089)$ & $(0.091)$ & $(0.086)$ \\
\hline \multirow[t]{2}{*}{ Real per capita GDP } & -0.101 & $0.270^{* *}$ & 0.157 & -0.190 & $0.266^{* *}$ & 0.113 \\
\hline & $(0.122)$ & $(0.106)$ & $(0.101)$ & $(0.115)$ & $(0.118)$ & $(0.112)$ \\
\hline \multirow[t]{2}{*}{ Education expenditure (\% of GDP) } & -0.013 & 0.021 & -0.013 & -0.013 & 0.015 & -0.020 \\
\hline & $(0.022)$ & $(0.019)$ & $(0.018)$ & $(0.019)$ & $(0.019)$ & $(0.018)$ \\
\hline \multirow{3}{*}{$\begin{array}{l}\text { Urban population } \\
\text { (\% of total population) }\end{array}$} & & & & & & \\
\hline & -0.005 & -0.005 & -0.002 & -0.007 & -0.002 & -0.002 \\
\hline & $(0.007)$ & $(0.006)$ & $(0.005)$ & $(0.006)$ & $(0.006)$ & $(0.006)$ \\
\hline \multirow[t]{2}{*}{ Minimum wage } & 0.037 & $-0.090^{* * *}$ & $-0.057^{* *}$ & $0.067^{* *}$ & $-0.088^{* *}$ & -0.047 \\
\hline & $(0.033)$ & $(0.029)$ & $(0.028)$ & $(0.032)$ & $(0.033)$ & $(0.031)$ \\
\hline \multirow[t]{2}{*}{ Primary completion rate } & $0.464^{*}$ & -0.158 & -0.280 & 0.292 & -0.183 & -0.152 \\
\hline & $(0.253)$ & $(0.221)$ & $(0.210)$ & $(0.227)$ & $(0.233)$ & $(0.221)$ \\
\hline \multirow[t]{2}{*}{ Working-age population } & -1.003 & 0.248 & $-1.744^{* *}$ & -1.205 & 0.071 & $-2.013^{* *}$ \\
\hline & $(0.934)$ & $(0.815)$ & $(0.777)$ & $(0.820)$ & $(0.840)$ & $(0.795)$ \\
\hline \multirow[t]{2}{*}{ Constant } & 2.771 & -1.673 & $7.757^{* *}$ & 4.953 & -0.885 & $8.591^{\text {** }}$ \\
\hline & (4.109) & $(3.588)$ & $(3.420)$ & $(3.690)$ & $(3.781)$ & (3.579) \\
\hline Observations & 85 & 85 & 85 & 85 & 85 & 85 \\
\hline$R^{2}$ value & 0.445 & 0.564 & 0.409 & 0.636 & 0.607 & 0.474 \\
\hline Number of countries & 13 & 13 & 13 & 13 & 13 & 13 \\
\hline
\end{tabular}

GDP = gross domestic product, ICT = information and communication technology, PPP = public-private partnership.

Notes: Standard errors in parentheses. ${ }^{* *} p<0.01^{* *} p<0.05^{*} p<0.1$.

Source: Authors' estimates. 


\section{Table A4: Education PPP and Enrollment Rates}

\begin{tabular}{lcr}
\hline Variable & $\begin{array}{c}\text { Primary Enrollment } \\
\text { Rate }\end{array}$ & $\begin{array}{c}\text { Secondary } \\
\text { Enrollment Rate }\end{array}$ \\
\hline PPP investment in education & $0.00284^{*}$ & $0.00821^{* *}$ \\
Population density (people per square kilometer of land area) & $(0.00148)$ & $(0.00376)$ \\
Urban population (\% of population) & 0.0023 & 0.0240 \\
& $(0.00364)$ & $(0.00553)$ \\
Education expenditure (\% of GDP) & $0.061^{* *}$ & $0.359^{*}$ \\
& $(0.0246)$ & $(0.0732)$ \\
Public health expenditure (\% of GDP) & -0.026 & $0.132^{*}$ \\
Constant & $(0.0298)$ & $(0.0704)$ \\
& $0.059^{* * *}$ & $0.179^{* * *}$ \\
Observations & $(0.0148)$ & $(0.0345)$ \\
$R^{2}$ value & $4.165^{* * *}$ & $2.348^{* * *}$ \\
Number of countries & $(0.0913)$ & $(0.3040)$ \\
\hline
\end{tabular}

GDP = gross domestic product, PPP = public - private partnership .

Notes: All variables in logs. Sample includes developed Asian economies from the IJGlobal database. Standard errors in parentheses. *** $p<0.01^{* *} p<0.05^{*} p<0.1$.

Source: Authors' estimates. 


\section{REFERENCES}

Arezki, Rabah, Patrick Bolton, Sanjay Peters, Frederic Samama, and Joseph Stiglitz. 2016. "From Global Savings Glut to Financing Infrastructure: The Advent of Investment Platforms." IMF Working Paper No. WP/16/18.

Aschauer, David A. 1989. “Is Public Expenditure Productive?” Journal of Monetary Economics 23 (2): 177-200.

Asian Development Bank (ADB). 2017. Meeting Asia's Infrastructure Needs. Manila.

Barro, Robert J. 1990. "Government Spending in a Simple Model of Endogenous Growth." Journal of Political Economy 98 (5): 103-25.

Barro, Robert J., and Xavier Sala-i-Martin. 2004. Economic Growth, 2nd ed. Cambridge, MA: MIT Press.

Calderón, César, and Alberto Chong. 2004. "Volume and Quality of Infrastructure and the Distribution of Income: An Empirical Investigation." Review of Income and Wealth 50 (1): 87-106.

Calderón, César, Enrique Moral-Benito, and Luis Servén. 2015. “Is Infrastructure Capital Productive? A Dynamic Heterogenous Approach.” Journal of Applied Econometrics 30 (2): 177-98.

Calderón, César, and Luis Servén. 2004. "The Effects of Infrastructure Development on Growth and Income Distribution.” World Bank Working Paper No. WPS3400.

2010. "Infrastructure and Economic Development in Sub-Saharan Africa." Journal of African Economies 19 (1): 13-87.

2014. "Infrastructure, Growth, and Inequality: An Overview. Policy Research.” World Bank Working Paper No. 7034.

Canning, David, and Peter Pedroni. 2008. "Infrastructure, Long-Run Economic Growth and Causality Tests for Cointegrated Panels.” Manchester School 76 (5): 504-27.

Cerra, Valerie, Alfredo Cuevas, Carlos Goes, Izabela Karpowicz, Troy Matheson, Issouf Zamake, and Svetlana Vtyurina. 2016. "Highways to Heaven: Infrastructure Determinants and Trends in Latin America and the Caribbean.” IMF Working Paper No. WP/16/185.

Davies, Paul, and Kathryn Eustice. 2005. "Delivering the PPP Promise: A Review of PPP issues and Activity. PricewaterhouseCoopers." http://www.globalclearinghouse.org/InfraDev/assets/10/ documents/PWC\%20-\%20Delivering\%20the\%20PPP\%20Promise_A\%20Review\%20of\%20 PPP\%20lssues\%20and\%20Activities\%20(2005).pdf.

de Bettignies, Jean-Etienne, and Thomas W. Ross. 2004. "The Economics of Public-Private Partnerships." Canadian Public Policy 30 (2): 135-54.

Dintilhac, Clio, Fernanda Ruiz-Nuñez, and Zichao Wei. 2015. "The Economic Impact of Infrastructure and Public-Private Partnerships: Literature Review." https://library.pppknowledgelab.org/ World\%20Bank\%20Group/documents/2384. 
The Economist Intelligence Unit. 2014. The 2014 Infrascope Index and Report. London.

Engel, Eduardo. 2016. "Public-Private Partnerships: Economic Theory and Public Policy." Presentation at the World Bank Development Economics Vice Presidency (DEC) Lecture Series, Washington DC, 22 March.

European PPP Expertise Centre. 2015. "PPP Motivations and Challenges for the Public Sector: Why (Not) and How?” http://www.eib.org/attachments/epec/epec_ppp_motivations_and_challenges_en.pdf.

Futagami, Koichi, Yuichi Morita, and Akihisa Shibata. 1993. "Dynamic Analysis of an Endogenous Growth Model with Public Capital." The Scandinavian Journal of Economics 95 (4): 607-25.

Gutierrez, Catalina, Carlo Orecchia, Pierella Paci, and Pieter Serneels. 2007. "Does Employment Generation Really Matter for Poverty Reduction?” World Bank Policy Research Working Paper No. 4432.

Hammami, Mona, Jean-Francois Ruhashyankiko, and Etienne B. Yehoue. 2006. "Determinants of Public-Private Partnerships in Infrastructure.” IMF Working Paper No. WP/06/99.

Han, Xuehui, and Shang-Jin Wei. 2017. "Reexamining the Middle-Income Trap Hypothesis (MITH): What to Reject and What to Revive?" Journal of International Money and Finance 73: 41-61.

Henckel, Timo, and Warwick McKibbin. 2010. The Economics of Infrastructure in a Globalized World: Issues, Lessons and Future Challenges. Washington, DC: Brookings.

Ismail, Normaz Wana, and Jamilah Mohd Mahyideen. 2015. "The Impact of Infrastructure on Trade and Economic Growth in Selected Economies in Asia.” ADBI Working Paper Series No. 553.

lossa, Elisabetta, and David Martimort. 2015. "The Simple Microeconomics of Public-Private Partnerships." Journal of Public Economic Theory 17 (1): 4-48.

John, Prachitha, Ashwin Mahalingam, Akash Deep, and A. Thillairajan. 2015. "Impact of Private Sector Participation on Access and Quality of Services: Systematic Review of Evidence from the Electricity, Telecommunications and Water Supply Sectors." Journal of Development Effectiveness 7 (1): 64-89.

Kappeler, Andreas, and Mathieu Nemoz. 2010. "Public-Private Partnerships in Europe - Before and During the Recent Financial Crisis." Economic and Financial Report 2010/04. European Investment Bank. http://www.eib.org/attachments/efs/efr_2010_v04_en.pdf.

Kim, Jay-Hyung, Jungwook Kim, Sunghwan Shin, and Seung-Yeon Lee. 2011. Public-Private Partnership Infrastructure Projects: Case Studies from the Republic of Korea: Volume 1: Institutional Arrangements and Performance. Manila: Asian Development Bank.

Kodongo, Odongo, and Kalu Ojah. 2016. "Does Infrastructure Really Explain Economic Growth in SubSaharan Africa?" Review of Development Finance 6 (2): 105-25.

Kwon, Eunkyung. 2005. "Infrastructure, Growth and Poverty Reduction in Indonesia: A Cross-Sectional Analysis." Paper presented at the Asian Development Bank Institute Workshop on Transport Infrastructure and Poverty Reduction, Manila, 18-22 July. 
Mendoza, Octasiano Miguel V. 2017. "Infrastructure Development, Income Inequality, and Urban Sustainability in the People's Republic of China.” ADBI Working Paper Series No. 713.

Pritchett, Lant, and Lawrence Summers. 2014. "Asiaphoria Meets Regression to the Mean." NBER Working Paper No. 20573.

Rhee, Chang-Yong, and Hangyong Lee. 2007. "Public-Private Partnerships in Infrastructure and Macroeconomy: The Experience of Korea." In Performance Evaluation and Best Practice of PublicPrivate Partnerships, edited by Jay-Hyung Kim. Sejong: Korea Development Institute.

Romp, Ward, and Jakob de Haan. 2005. "Public Capital and Economic Growth: A Critical Survey." In Innovative Financing of Infrastructure - The Role of Public-Private Partnerships: Infrastructure, Economic Growth, and the Economics of PPPs, edited by Armin Riess and Timo Välilä.

Schomaker, Rahel. 2014. "Institutional Quality and Private Sector Participation: Theory and Empirical Findings." European Journal of Government and Economics 3 (2): 104-17.

Seethepalli, Kalpana, Maria Caterina Bramati, and David Veredas. 2008. "How Relevant is Infrastructure to Growth in East Asia?” World Bank Policy Research Working Paper No. 4597.

Servén, Luis. 2010. "Infrastructure and Growth." A World Bank Research Brief. http://econ.worldbank.org/WBSITE/EXTERNAL/EXTDEC/EXTRESEARCH/0,,contentMDK:2 2629797 pagePK:64165401 piPK:64165026 theSitePK:469382 isCURL:Y,00.html.

Setboonsarng, Sununtar. 2010. “Transport Infrastructure and Poverty Reduction.” ADBI Research Policy Brief No. 21.

Shediac, Richard, Rabih Abouchakra, Mona Hammami, and Mazen Ramsay Najjar. 2008. Public-Private Partnerships: A New Catalyst for Economic Growth. New York, NY: Booz \& Company.

Straub, Stéphane, and Akiko Terada-Hagiwara. 2010. "Infrastructure and Growth in Developing Asia." ADB Economics Working Paper Series No. 231.

Trujillo, Lourdes, Noelia Martin, Antonio Estache, and Javier Campos. 2002. "Macroeconomics Effects of Private Sector Participation in Latin America's Infrastructure.” World Bank Policy Research Working Paper No. 2906.

United Nations Economic and Social Commission for Asia and the Pacific (UNESCAP). 2014. "5P Approach: Partnerships for a Resilient Energy Future." http://www.unescap.org/sites/default/ files/5P_Brochure.pdf (accessed 14 June 2017).

Wallich, Christine. 2002. "Soft Hearts and Hard Heads: The Private Sector's Centrality to Poverty Reduction." In Defining an Agenda for Poverty Reduction: Proceedings of the First Asia and Pacific Forum on Poverty (Volume 1), edited by Christopher Edmonds and Sarah Medina. Manila: ADB.

Warner, Andrew. 2014. "Public Investment as an Engine of Growth.” IMF Working Paper No. WP/14/148.

World Bank. Private Participation in Infrastructure database. https://ppi.worldbank.org/data. 2016. Benchmarking Public-Private Partnerships Procurements. Washington, DC. 


\section{Deriving Macroeconomic Benefits from Public-Private Partnerships in Developing Asia}

Public-private partnership (PPP) projects on infrastructure development in developing Asia started to increase rapidly from the late 1990s. This paper explores the effectiveness of structural and functional features of PPPs on infrastructure development in boosting economic growth. It also shows how PPPs can bring macroeconomic benefits in developing Asia. Policy recommendations for the public sector are geared towards enabling institutional improvements on PPPs, such as legal and regulatory frameworks that ensure efficient competitive arrangements and high regard for social welfare.

\section{About the Asian Development Bank}

ADB is committed to achieving a prosperous, inclusive, resilient, and sustainable Asia and the Pacific, while sustaining its efforts to eradicate extreme poverty. Established in 1966, it is owned by 67 members48 from the region. Its main instruments for helping its developing member countries are policy dialogue, loans, equity investments, guarantees, grants, and technical assistance. 